\title{
Akıllı Turizm Araç ve Uygulamalarına İlişkin Turizm İşletmesi Yöneticilerinin Görüşleri: Eskişehir Üzerine Nitel Bir Araştırma \\ (Tourism Managers Opinions About Smart Tourism Vehicles and Applications: A Qualitative Research on Eskişehir)
}

\author{
Neşe KAFA iD a Reşat ARICA (iD) b Nagehan SÖNMEZ GÖK iD c \\ a Çanakkale Onsekiz Mart Üniversitesi, Turizm İşletmeciliği, Çanakkale, Türkiye nesekafa@comu.edu.tr \\ b Adıyaman Üniversitesi, Turizm Fakültesi, Adıyaman, Türkiye. rarica@adiyaman.edu.tr \\ c Anadolu Üniversitesi, Eskişehir Meslek Yüksekokulu, Eskişehir, Türkiye. nagehans@anadolu.edu.tr
}

\begin{tabular}{|c|c|}
\hline MAKALE & ZET \\
\hline $\begin{array}{l}\text { Anahtar Kelimeler: } \\
\text { Akıllı Turizm } \\
\text { Akıllı Destinasyon } \\
\text { Akıllı Şehir } \\
\text { Eskişehir }\end{array}$ & $\begin{array}{l}\text { Amaç - Araştırmanın amacı, Eskişehir'de faaliyet gösteren turizm işletmeleri yöneticilerinin akıllı } \\
\text { turizm uygulamalarına ilişkin görüşlerinin belirlenmesidir. Aynı zamanda işletmelerde kullanılan } \\
\text { akıllı teknolojik sistem ve araçların tespiti amaçlanmaktadır. } \\
\text { Yöntem - Araştırma nitel bir çalışma olarak tasarlanmıştır. Verilerinin derlenmesinde yarı- } \\
\text { yapılandırılmış görüşme tekniğinden faydalanılmıstır. Derlenen verilerin analizinde içerik analizi ve } \\
\text { betimsel analiz yöntemleri kullanılmıştır. }\end{array}$ \\
\hline $\begin{array}{l}\text { Gönderilme Tarihi } 22 \\
\text { Haziran } 2020 \\
\text { Revizyon Tarihi } 7 \text { Eylül } 2020 \\
\text { Kabul Tarihi } 15 \text { Eylül } 2020\end{array}$ & $\begin{array}{l}\text { Bulgular - Araştırmada elde edilen bulgulara göre, işletme yöneticileri akıllı turizm teknolojilerinin } \\
\text { sektör için bir gereklilik olduğunu ve destinasyonların pazardaki rekabet gücünü arttırdığını } \\
\text { düşünmektedir. Ayrıca, işletmelerin tamamına yakınında akıllı sistemlerle desteklenen modül ve } \\
\text { uygulamaların mevcut olduğu ancak, işletmelerde akıllı sistemlerin kullanımının yeterince gelişim } \\
\text { göstermediği bulgusuna ulaşılmıştır. Gelişimin önündeki temel engellerin ekonomik kısıtlar, altyapı } \\
\text { yetersizlikleri ve pazar koşullarından kaynaklandığı belirlenmiştir. }\end{array}$ \\
\hline $\begin{array}{l}\text { Makale Kategorisi: } \\
\text { Araştırma Makalesi }\end{array}$ & $\begin{array}{l}\text { Tartışma - Akıllı turizm sistemleri Eskişehir'de henüz yatırım ve gelişme aşamasındadır. Buna karşın, } \\
\text { işletme yöneticilerinin çoğunun akıllı teknolojilerin kullanımının işletmelere sağlayacağı fırsatlara } \\
\text { ilişkin bilgi ve farkındalığı bulunmaktadır. Bu durum akıllı teknolojik sistemlerin bölge ve işletmede } \\
\text { uygulanmasını engelleyen unsurların ortadan kaldırılması veya azaltılmasıyla işletmelerin kullanım } \\
\text { eğilimlerinin artış göstereceğine dair ipuçları sunmaktadır. Araştırmada ulaşıllan sonuçlar, akıllı şehir } \\
\text { olan Eskişehir'de turizm işletmelerinin akıllı sistemlerden faydalanma durumunun saptanması ve } \\
\text { eksiklikleri ortaya koyması yönüyle sektöre ve alanyazına katkı sağlayacaktır. }\end{array}$ \\
\hline
\end{tabular}

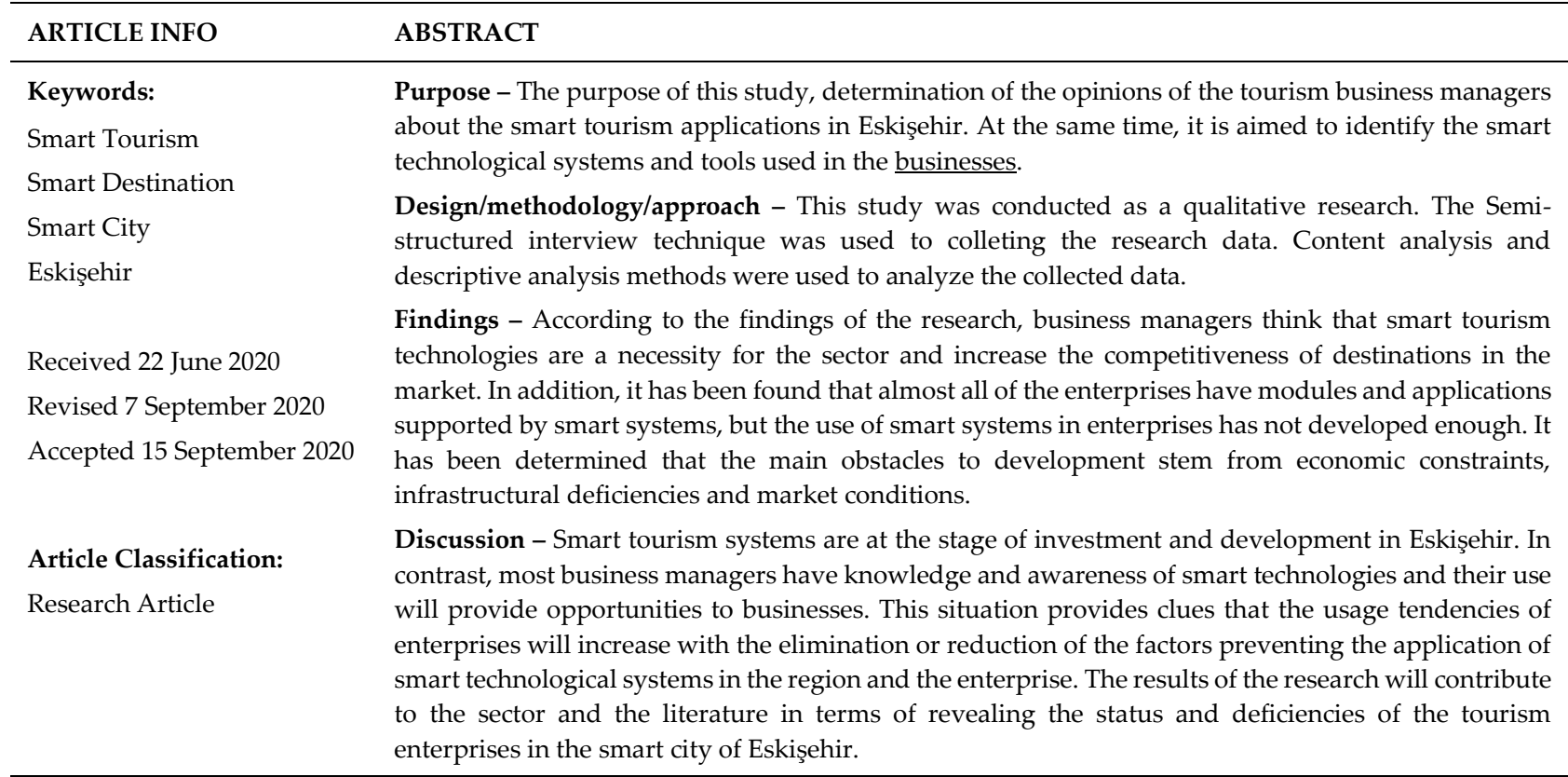




\section{GİRIŞ}

Bilgi ve iletişim teknolojilerinin günden güne daha fazla yaygınlaşması ve kullanım alanlarının çeşitlenmesi turizm sektöründe arz ve talep boyutuyla büyük değişimlerin yaşanmasına neden olmuştur. Günümüzde turizmin talep boyutunu oluşturan "yeni" turistlerin ihtiyaçları ve davranış kalıpları teknoloji öncesi dönemlere nispeten farklılık göstermektedir. Bu turistler, bilgi teknolojisine bağımlı hale gelirken, teknolojik olanaklara kolay erişime, teknolojik çeşitliliğe, esneklik ve güvenirlik unsurlarına daha fazla önem vermektedir (Wang vd., 2013: 310). Turistlerin teknoloji odaklı talepleri turizm sektöründe son yıllarda teknoloji odaklı bir yapının gelişmesine zemin hazırlarken, zaman içerisinde taşınamaz teknolojilerden taşınabilir teknolojilere ve ardından mobil teknolojiler, akıllı teknolojiler ve yapay zekâ teknolojilerinin turizm sektöründe kullanımını arttırmıştır (Buonincontri ve Micera, 2016; Arıca, 2019). Turizm sektöründe teknolojik kullanım ve uygulama alanlarının gelişimi, sektör paydaşlarına teknoloji tabanlı etkili ve verimli çözümler sunmayı amaçlayan akıllı şehirlerin (Khan vd., 2017: 1) ve akıllı turizm destinasyonlarının ortaya çıkmasına zemin hazırlamıştır (Yalçınkaya vd., 2018: 34).

Lazaroiu ve Roscia (2012)'ye göre akıllı şehir, teknolojinin ekonomik ve sosyal yaşam kalitesinin iyileştirilmesine hizmet ettiği bir şehir modelini temsil etmektedir. Akıllı turizm ise, akıllı şehir konseptinin bir alt kümesi olarak kabul görmektedir. Akıllı şehir ve akıllı turizm kavramları, içerdikleri ortak unsurlar itibariyle birbiriyle yakından ilişkilidir. İki kavram arasındaki en büyük fark akıllı şehirlerin yerel halka hizmet etmesi, akıllı turizm destinasyonlarının ise çoğunlukla turistlere yönelik olmasıdır (Khan vd., 2017). Buhalis ve Amaranggana (2013) akıllı turizm destinasyonunu, bilgi iletişim teknolojilerinin turizm faaliyetleriyle ilgili bilgi alışverişinin geliştirilmesi, paydaşlar arası iletişim ve etkileşimin sağlanması ve beraber karar alma süreçlerinin geliştirilmesinde kullanılması olarak açıklamaktadır. Turizm sektörünün bilgi ve iletişim teknolojilerinin kullanımına uygunluğu, sektörel düzeyde akıllı turizm araçlarından faydalanılmasını ve akıllı turizm destinasyonlarının sayısının hızla artış göstermesini olanaklı kılmaktadır (Koo vd., 2016: 566). Akıllı şehir, akıllı turizm ve akıllı destinasyon kavramlarının uygulamadaki gelişimiyle, bu kavramlara yönelik incelemeler ve tartışmalar yapılmıştır.

Literatürdeki çalışmaların bir kısmında akıllı turizm ekosistemi ve bilgi teknolojileri arasındaki ilişki incelenmiştir. Bu çalışmalara göre, akıllı teknolojiyle elde edilen bilgiler, turizme entegre edilebilmektedir (Gretzel vd., 2015; Polese vd., 2018; Vecchio vd., 2018; Arenas vd., 2019). Çalışmaların bir kısmında akıllı teknolojilerin destinasyon kapsamında sağlayacağı yararlar ele alınmıştır (Afsarmanesh ve Camarinha-Matos, 2000; Kuşat, 2011; Wang vd., 2013; Guo vd., 2014; Gretzel vd., 2015; Koo vd., 2016; Vecchio vd., 2018; Arenas vd., 2019). Bu çalışmalarda akıllı teknolojinin turizm sektöründe rekabet avantajı (Kuşat, 2011; Koo vd., 2016) ve müşteri memnuniyetini sağlayacağı (Li vd., 2017) tespit edilmiştir.

Çeşitli çalışmalarda akıllı turizm uygulamaları farklı destinasyonlar ekseninde değerlendirilmiştir. Graziano (2014) İtalya'y1; Buonincontri ve Micera (2016) Venedik ve Salzburg'u; Çelik ve Topsakal (2017) Antalya'y1; Khan vd., (2017) Dubai'yi; Li vd. (2017) Çin'i; Liberato vd., (2018) Porto'yu; Arenas vd., (2019) İspanya'yl; Zencir ve Emir (2020) Eskişehir'i akıllı turizm destinasyonları kapsamında değerlendirmiştir. Mevcut çalışmaların bir kısmında akıllı turizm destinasyonlarının farklı bölgeler düzeyinde değerlendirilmesinin literatüre önemli katkı sunacağı ifade edilmiştir (Polese vd., 2018; Arenas vd., 2019). Buradan hareketle hazırlanan araştırmanın amacı, Eskişehir'de faaliyet gösteren turizm işletmesi yöneticilerinin akıllı turizm uygulamalarına ilişkin görüşlerinin belirlenmesidir. Bununla birlikte araştırmada, turizm işletmelerinde kullanılan akıllı teknolojik sistem ve araçların tespiti amaçlanmaktadır. Araştırmada Türkiye'nin ilk akıllı şehirlerinden biri olan Eskişehir'deki akıllı turizm sistemleri üzerine odaklanılmış ve bu konudaki mevcut duruma ilişkin tespitler yapılmıştır. Eskişehir'in akıllı turizm sistemlerini uygulamaya yeni geçtiği bir şehir hüviyeti taşıması, araştırmayı gelişim süreç ve dinamiklerine katkı sunması bağlamında önemli kılmaktadır.

\section{LİTERATÜR}

Akıllı şehir, bağımsız ve farkındalığı yüksek vatandaşların olduğu, akıllı kombinasyonlar üzerine inşa edilmiş ekonomi, insanlar, yönetişim, hareketlilik, çevre ve yaşam alanlarında ileriye dönük performans gösteren bir kent olarak tanımlanmaktadır (Giffinger vd., 2007). Barrionuevo, Pascual ve Ricart'a (2012) göre ise akıllı şehir, aynı anda entegre, yaşanabilir ve sürdürülebilir şehir merkezlerini geliştirmek için akıllı ve koordineli bir şekilde, mevcut tüm teknoloji ve kaynaklarının kullanıma sunulduğu kenttir. Giffinger vd. (2007) akıllı şehirlerin karakteristiklerini altı grupta ele almaktadır. Bunlar; akıllı ekonomi, akıllı hareketlilik (akıllı ulaşım), 
akıllı yaşam, akıllı çevre, akıllı insan, akıllı yönetişimdir. Bu karakteristik özellikleri destekleyen bir fikirde Avrupa Birliği tarafından ortaya konmuştur. Buna göre akıllı şehirlerin karakteristikleri; akıllı yönetişim, akıllı insan, akıllı yaşam, akıllı mobilite, akıllı ekonomi ve akıllı çevredir. (Lazaroiu ve Roscia, 2012: 326). Türkiye'de ise Çevre ve Şehircilik Bakanlığı (2019) tarafından 2019-2022 Ulusal Akıllı Şehirler Stratejisi ve Eylem Planında akıllı şehirlerle ilgili 17 bileşenden oluşan bir yapı tanımlanmıştır. Bunlar; akıllı çevre, akıllı güvenlik, akıllı insan, akıllı yapılar, akıllı ekonomi, akıllı mekân yönetimi, akıllı sağlık, akıllı yönetişim, bilgi teknolojileri, akıllı ulaşım, akıllı enerji, iletişim teknolojileri, bilgi güvenliği, akıllı altyapı, coğrafi bilgi sistemleri, afet ve acil durum yönetim sistemleridir (Çevre ve Şehircilik Bakanlığı, 2019: 15). Gerek araştırmalar, gerekse uluslararası ve ulusal ölçekte tanımlanan akıllı şehir bileşenleri farklı sektörlerde uygulama alanı bulmuştur. Akıllı şehir sistemlerinin turizm sektöründe uygulamadaki karşılı̆̆ 1 akıllı turizm ve akıllı destinasyon biçiminde olmuştur.

Akıllı turizm, sürdürebilirliğe, verimliliğe ve turist deneyimlerini zenginleştirmeye odaklanarak ileri teknolojilerin kullanılmasıyla devlet/örgütsel kaynaklar, fiziksel altyapı, sosyal bağlantılar ve insan bedenleri/zihinlerinden sağlanan verilerin toplanması ile elde edilen verileri turist deneyimleri ve işletmenin uygulamalarına entegre etmek için bir destinasyonda sağlanan çabaları ifade etmektedir (Gretzel vd., 2015: 181). Wang vd. (2013), akıllı turizmi çok yönlü bir yapı olarak değerlendirmekte ve bu yapının dinamikliğinin, etkinliğinin ve verimliliğinin birçok bileşenle ilişkili olduğunu savunmaktadır. Literatürde akıllı turizmin bileşenleri farklı çerçevelerden ele alınırken, genel içeriği şöyle açıklanmaktadır (Bkz: Şekil 1).

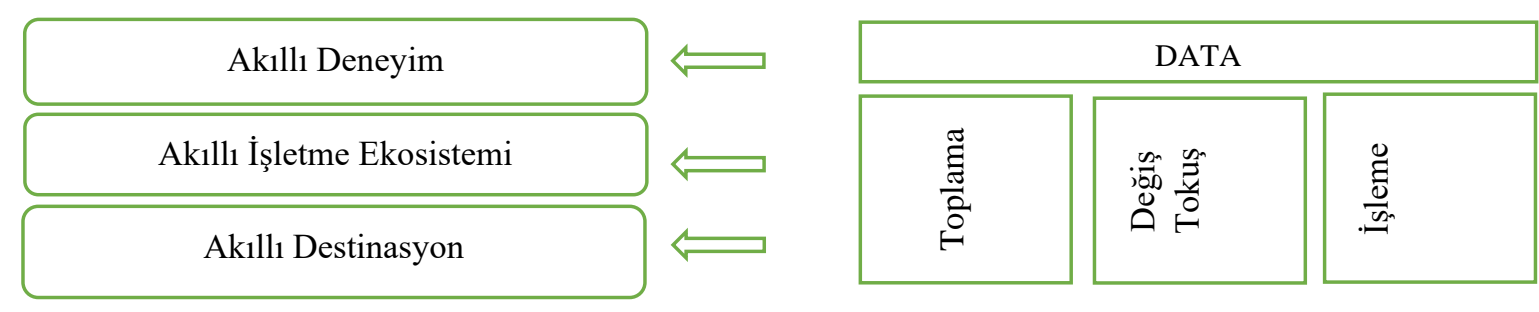

Şekil 1: Akıllı Turizmin Bileşenleri

Kaynak: Gretzel, Sigala, Xiang ve Koo, 2015: 181

Akıllı turizmin bileşenleri, 'veri toplama ve depolama, işleme, birleştirme, analiz etme ve kullanma' işlemlerini içermektedir (Gretzel vd., 2015: 183). Zhang'a (2012) göre akıllı turizmde verilerin toplanması, işlenmesi ve paylaşılması turizm ekosistemi içindeki temel işlevlerden biridir. Veri derleme, akıllı turizmin ekosistemini oluşturan turist ve yerel halk, turizm tedarikçileri ve turizm aracıları, medya, destek hizmetleri, seyahat teknolojisi ve veri şirketleri arasındaki işlemleri kolaylaştırmak adına elzemdir. Bu verilerle turistik deneyimler oluşturulmakta, yönetilmekte ve sunulmaktadır. Veri sürecindeki başarı ekosistem içerisindeki tüm unsurların akıllı teknoloji kullanımına bağlıdır. Akıllı teknolojilerin tüm turizm paydaşları tarafından kullanıldığı yapı ise akıllı turizm destinasyonu olarak kabul edilmektedir (Boes vd., 2016).

Akıllı turizm ekosistemlerinin bir çıktısı olarak kabul gören akıllı turizm destinasyonları literatürde farklı şekillerde açıklanmaktadır. Buhalis ve Amaranggana (2013) akıllı turizm destinasyonlarını bilgi ve iletişim teknolojilerinin yoğun bir biçimde kullanıldığı ve paydaşlar arasındaki koordinasyonun teknolojiyle sağlandığı yapı olarak izah etmektedir. Boes vd. (2016) ise akıllı turizm destinasyonlarını mevcut teknolojik araç ve teknikleri çeşitli faydalar sağlamak üzere kullanan bölgeler olarak tanımlamaktadır. Lamsfus vd. (2015) akıllı turizm destinasyonlarını turist eksenli bakış açısıyla değerlendirirken, ürünleri kişiselleştirme ve bu sayede turistik deneyim kalitesini arttırma, turistlerin destinasyonda ulaşabilecekleri hizmet ve ürünlerinden haberdar olmalarını sağlama, teknolojik altyapıyı yoğun olarak kullanabilmelerini mümkün kılma ve turistlerden elde edilen verilerle destinasyon yönetim organizasyonlarını güçlendirme amaçlı geliştirilen bir yapı olarak açıklamaktadır. Lopez de Avila'ya (2015) göre akıllı turizm destinasyonu, son teknoloji ürünlerle kurgulanan bir altyapı aracıllğıyla turistlerin çevresiyle etkileşim ve entegrasyonunu kolaylaştıran, destinasyondaki deneyim kalitesini ve bölge sakinlerinin yaşam kalitesini artıran, turistik alanların sürdürülebilir kalkınmasını daha makul kılan ve yenilikçi bir turizmin oluşturulması için önemli işlev gören bir sistemdir. Akıllı turizm destinasyonları teknolojik araç ve sistemlerin kullanıldığı, bu sayede günümüz pazar koşulları ve talep yapısının istekleriyle uyumlu hizmet sunulan bir sistem olarak açıklamak mümkündür. Bu sistemin başlıca unsuru olan teknolojinin etkin ve verimli kullanımı sayesinde ülke, bölge ve 


\section{N. Kafa - R. Arıca - N. Sönmez Gök 12/3 (2020) 2774-2787}

işletmelerin makro ölçekli değişimlere karşıllk vermesi hedeflenmektedir. Taşınamaz, taşınabilir, mobil, akıllı ve yapay zekâ teknolojiler olarak bilinen birçok farklı sistem akıllı turizm destinasyonlarında farklı alanlarda kullanım imkânı bulmaktadır. Literatürde akıllı destinasyonlarında kullanılan teknolojiler ve kullanım alanları farklı şekillerde ifade edilmektedir.

Gretzel vd.'ne (2006: 10) göre akıllı turizm destinasyonlarında interaktif web siteleri, sanal topluluklar, sosyal medya ağları ve mobil teknolojiler gibi bilişim teknolojileri, seyahat öncesi, seyahat esnası ve seyahat sonrasında turistik deneyimini desteklemek için kullanılmaktadır. Buhalis ve Amaranggana (2013) akıllı turizm destinasyonlarında, mobil uygulamalar, yakın alan iletişim sistemleri (NFC) ve QR kod modüllerinin kullanıldığını ifade etmektedir. Le'ye (2014) göre akıllı turizm destinasyonlarda bilgi teknolojilerinin kullanım alanları; etkileşimli platformlar arası web siteleri, çevrimiçi rezervasyon sistemleri, sanal seyahat toplulukları, mobil uygulamalar, sanal arıtılmış gerçeklik uygulamaları, e-ticaret faaliyetlerine uyumlu yapı ve çok yönlü deneyim sistemleridir. Liberato vd. (2018) bu sistemlere bağlı olarak mobil ödeme, bilgi edinme ve iletişim, konum bilgisine erişim, müze ve anıt ziyaretlerinde kullanılan akıllı uygulamaları teknolojinin turizm destinasyonlarında kullanımı ve akıllı destinasyon kapsamında açiklamaktadır. Bu teknolojilerin destinasyonlarda kullanımı bölgedeki turistik paydaşların çeşitli fırsatlar elde etmesini sağlamaktadır (Vecchio vd., 2018). Literatürde yer alan bazı çalışmalarda akıllı turizm sistemlerinin kullanımının destinasyonlar (Boes vd. 2015; Çelik ve Topsakal, 2017; Vecchio vd., 2018), işletmeler (Li vd., 2017; Yalçınkaya vd., 2018; Vecchio vd., 2018) ve turistler (Arenas vd., 2019) için bir takım çıktıları beraberinde getirdiği belirlenmiştir.

Çelik ve Topsakal (2017) gelecekte akıllı turizm destinasyonlarının sektörde önemli rekabet aracı haline geleceğini belirtmektedir. Buhalis ve Amaranggana (2013) bilgi iletişim teknolojilerinin turizm sektöründeki paydaşların turistik hizmet üretim ve yönetim aşamalarında koordine olabilmelerini sağladığını ve bunun turistik deneyim kalitesini etkilediğini açıklamaktadır. Bir diğer çalışmada Boes vd. (2015) akıllı turizm destinasyonlarının yerel halk üzerindeki olumlu etkisine dikkat çekmektedir. Buna göre, halkın turizm faaliyetlerine desteği bölgede turizm faaliyetlerinin gelişiminde önemli etkiye sahiptir. Destek ise halkın turizmden elde ettiği faydayla ilişkilidir. Dolayısıyla akıllı turizm destinasyonlarıyla halkın turizmden elde edeceği fayda düzeyinin arttırılması, bölgenin gelişim ve rekabet gücünde belirleyici olacaktır. Lamsfus vd. (2015) ise akıllı turizm destinasyonlarında artan bilgi akış ve kalite hızının destinasyon yönetim organizasyonlarının güçlendirilmesine olanak tanıdığını ifade etmektedir. Destinasyonların elde ettiği faydalar işletmeler ve turistler üzerinde de etkili olacaktır. Dolayısıyla destinasyonlarda akıllı sistemlere entegrasyonun arz ve talep yönlü çıktıları beraberinde getireceği aşikardır.

Vecchio vd. 'ne (2018: 858) göre akıllı teknoloji kullanımı işletmelere değer yaratma, karar verme, müşteri ilişkilerini geliştirme ve iş analizi yapma noktasında kolaylıklar sağlamaktadır. Ayrıca akıllı sistemlerin bir parçası olan bilgi teknolojileri sayesinde işletmelerin turist profillerini tanımlanması, turistlerin sosyodemografik özelliklerini belirlemesi, tercih ve düşüncelerini tahminlemesi mümkündür. Dahası, işletmelerin bu bilgilerle farklı zevklere sahip turistleri bölümlere ayırması ve onlar için yenilikçi ürünler sunulması olanaklı hale gelmektedir. Akıllı teknolojilerle işletmelerin turistik deneyimleri geliştirme ve denetleme imkânına kavuşmasıyla (Li vd., 2017: 298), müşteri memnuniyetinin arttırılması, rekabet üstünlügünün sağlanması, kâr marjının arttırılması, maliyetlerin azaltılması olası hale gelmektedir (Yalçınkaya vd., 2018: 47). Akıllı turizm destinasyonlarının işletmelere sağladığı faydalarla birlikte turistlere sağladığ faydaların değerlendirildiği araştırmalarda mevcuttur. Arenas vd. (2019: 153) akıllı turizm destinasyonlarının turistlere sağladığı faydaları şöyle açıklamaktadır: Akıllı turizm uygulamalarıyla turistler ücretsiz olarak tüm seyahat ihtiyaçları için gereken bilgiye ulaşabilmekte ve gezi planlaması gerçekleştirebilmektedir. Bu sistem aracılığıyla öncelikle turlarla ilgili tüm alternatifler listelenmekte ve işletmelerin web sitelerine doğrudan bağlantıların sağlanması sayesinde turistler rezervasyonlarını kendileri tamamlayabilmektedir. Bu durum turistin üretim sürecine katılımını sağlarken, hizmetleri istek ve ihtiyaçları doğrultusunda kişiselleştirmesine olanak tanımaktadır. Kişiselleşen hizmetler ise müşterilerin kalite ve değer algısı, tatmin ve sadakatini geliştirmektedir (Arıca, 2019). Arz ve talep unsurları odaklı çıktıları 1şığında, akıllı teknolojilerin destinasyonlarda ve işletmelerde kullanılmasının daha sürdürülebilir bir geleceğin oluşturulmasına yardımcı olacağını söylemek mümkündür (Graziano, 2014: 7). Bu çıktıların elde edilmesi ise sektörel ölçekte akıllı turizm bileşenlerinin etkin ve verimli yönetimiyle mümkündür. 


\section{YÖNTEM}

Eskişehir'in Tepebaşı ilçe (merkez) belediyesi 2013 yılında belediye merkez binası üzerine kurulumunu sağladığ güneş panellerinden elektrik üretme düşüncesiyle başladığı akıllı şehir yolculuğuna 2015 yılında "Akıllı Kentsel Dönüşüm Yenileme Modeli" projesiyle devam etmiştir (Zencir ve Emir, 2019; Karayılmaz ve Özker, 2020). Avrupa Birliği'nin bilimsel ve uygulamalı araştırma geliştirme inovasyon projelerine destek olmak üzere oluşturulan Ufuk 2020 kapsamında alınan proje, birinci nesil Akıllı Kent Projesidir. Tepebaşı Belediyesi (Türkiye), Valladolid Belediyesi (İspanya) ve Nottingham Kent Konseyi (Birleşik Krallık) konsorsiyumundan oluşan projeyle 22 Milyon Euro AB hibesini almaya hak kazanmıştır. Enerji, ulaşım, iletişim ve bilgi teknolojileri alanlarındaki yenilikler akıllı şehir uygulamalarına entegre edilmektedir. Proje kapsamında binalarda enerji verimliliğini arttıracak kaplama sistemleri oluşturulup güneş panelleri kurulmuş, elektrikli halk otobüsleri, hibrid otomobil, elektrikli bisikletler alınmış ve bisiklet yolu yapılmıştır. Tüm binalarda tüketilen enerjinin ne amaçla kullanıldığı ne kadarının yenilenebilir kaynaklardan hangi boyutta yararlanıldığını izlemek amacıyla web sayfası Akıllı Şehir İzleme Portalı oluşturulmuş ve çevre aydınlatmaları LED armatörlerle değiştirilmiştir (www.tepebasi.bel.tr). Enerjisini güneşten alan kent şarj istasyonları kurularak halkın hizmetine ücretsiz sunulmuş, yine enerjisini güneşten sağlayarak sıcak su ihtiyacını karşılayacak solar güneş panelleri ve organik atık yakan kazanlar hizmete sunulmuştur (Aksoğan ve Çalış Doğan, 2018).

Araştırmanın amacı, Eskişehir'de faaliyet gösteren turizm işletmesi yöneticilerinin akıllı turizm uygulamalarına ilişkin görüşlerinin belirlenmesidir. Bölge ve işletmelerde kullanılan akıllı teknolojilerin belirlenmesi için öncelikle yazın taraması yapılmış, ardından araştırmanın amacına uygun sorular oluşturulmuştur. Araştırma soruları oluştururken yararlanılan kaynaklar aşağıda yer almaktadır (Bkz: Tablo $1)$.

Tablo 1: Araştırma Soruları ve Uyarlandığı Çalışmalar

\begin{tabular}{|c|c|}
\hline Araştırma Sorusu & Kaynak \\
\hline $\begin{array}{l}\text { 1) Akıll turizm destinasyonu kavramın duydunuz mu? Duyduysanız bu kavramı } \\
\text { kısaca anlatır mısını? }\end{array}$ & Boes vd. 2016 \\
\hline 2) Akıllı turizm destinasyonlarının bölgeye să̆ladığı/să̆layacă̆ı firsatlar nelerdir? & $\begin{array}{c}\text { Arenas, Goh ve Urueña, } \\
\text { 2019; Vecchio, Mele, } \\
\text { Ndou ve Secundo, } 2018\end{array}$ \\
\hline $\begin{array}{l}\text { 3) İşletmenizde akıllı teknolojik araçlar kullanmakta mısınız? Kullanıyorsanız } \\
\text { kullandığını araçlar ve bu araçları kullanım amaçlarınız hakkında bilgi verir misiniz? }\end{array}$ & Le, 2014 \\
\hline $\begin{array}{l}\text { 4) İşletmenizin kendine ait mobil uygulaması mevcut mudur? Mevcut ise uygulamanın } \\
\text { sağlayıcıları ve içeriği hakkında kısaca bilgi verir misiniz? }\end{array}$ & $\begin{array}{l}\text { Arenas, Goh ve Urueña, } \\
2019\end{array}$ \\
\hline $\begin{array}{l}\text { 5) İşletmeniz velveya bölgedeki diğer turizm işletmelerinin akıllı teknolojik } \\
\text { uygulamalardan ve araçlardan yeterince faydalandığın düşünüyor musunuz? }\end{array}$ & $\begin{array}{l}\text { Arenas, Goh ve Urueña, } \\
2019\end{array}$ \\
\hline $\begin{array}{l}\text { 6) Akıllı teknolojilerin turizm sektöründe uygulanması noktasında karşılaşabilecekleri } \\
\text { engeller nelerdir? }\end{array}$ & $\begin{array}{c}\text { Arenas, Goh ve Urueña, } \\
2019\end{array}$ \\
\hline
\end{tabular}

Eskişehir'in Tepebaşı bölgesinin akıllı şehir uygulamalarına sahip olmasından ötürü araştırma alanı olarak şehrin bu bölgesindeki işletmelerden veri derlenmiştir. Örneklemin belirlenmesinde amaçlı örnekleme yönteminden faydalanılmıştır. Bu kapsamda Eskişehir'in Tepebaşı ilçesinde faaliyet gösteren ve akıllı teknolojileri en yoğun kullanan işletmeler belirlenmiş ve örnekleme dâhil edilmiştir. Konaklama işletmesi, seyahat acentaları, yiyecek ve içecek işletmeleri ve eğlence hizmetleri sunan işletmelerden oluşan toplamda sekiz ayrı işletme yöneticisiyle görüşme yapılarak araştırma verileri elde edilmiştir. Görüşme, insanların neyi ve neden düşündüklerini, duygu, tutum ve hislerinin neler olduğunu, davranışlarını yönlendiren etkenleri ortaya çıarmayı sağlayan veri toplama aracıdır (Ekiz, 2009: 62). Araştırmada görüşme tekniklerinden yarı- 
yapılandırılmış görüşme tekniğinden faydalanılmıştır. Yarı-yapılandırılmış görüşme tekniği, soruların önceden hazırlandığı ancak ortama göre görüşme sorularının sayısı ve sırasının değişebildiği, konunun gelişimine göre akla gelen soruların sorulabildiği ve cevaplar kayıt altına alındığı bir veri toplama yöntemidir (Kozak, 2014: 89). Araştırmanın verileri 05.11.2019 ve 25.11.2019 tarihleri arasında toplanmıştır. Görüşmeler yapılmadan önce işletme yöneticilerinden randevu alınmış ve daha önce belirlenen tarihlerde görüşmeler gerçekleştirilmiştir. Görüşme yapılan kişilerin işletmedeki pozisyonu ve görüşme süreleri Tablo 2'de yer almaktadır.

Tablo 2: Işsletme Türü, Kişinin Pozisyonu ve Görüşme Süresi

\begin{tabular}{|l|c|c|}
\hline \multicolumn{1}{|c|}{ İşletme Türü } & Görüşülen Kişinin İşletmedeki Pozisyonu & Görüşme Süresi \\
\hline Konaklama İşletmesi I & İşletme Müdürü & 26 dakika 02 saniye \\
\hline Konaklama İşletmesi II & İşletme Yöneticisi & 18 dakika 26 saniye \\
\hline Seyahat Acentası I & İşletme Sahibi & 14 dakika 17 saniye \\
\hline Seyahat Acentası II & İşletme Sahibi & 11 dakika 03 saniye \\
\hline Yiyecek ve İçecek İşletmesi I & İşletme Müdürü & 12 dakika 48 saniye \\
\hline Yiyecek ve İçecek İşletmesi II & İşletme Müdürü & 16 dakika 24 saniye \\
\hline Eğlence İşletmesi I & İşletme Müdürü & 9 dakika 34 saniye \\
\hline Eğlence İşletmesi II & İşletme Müdürü & 10 dakika 53 saniye \\
\hline
\end{tabular}

Görüşme yapılan kişilerin yarıdan fazlası işletmenin yönetici pozisyonunda çalışırken, görüşmelerin ortalama süresi yaklaşık 15 dakikadır. Yapılan görüşmeler katılımcıların onayı alınarak ses kayıt cihazıyla kayıt altına alınmıştır. Derlenen kayıtlar deşifre edilmiş, ulaşılan yazılı metinlerin analizinde içerik analizi ve betimsel analiz yöntemleri kullanılmıştır. İçerik analizi, yazılı metinlerin ya da söylemlerin içeriğine bakarak en çok ya da en az hangi kavramlara, olaylara veya düşüncelere vurgu yapıldığının belirlenmesi, bu yolla sonuca ulaşılmasıdır (Kozak, 2014: 138). İçerik analiziyle elde edilen vurgular betimsel analiz yöntemi kullanılarak ayrıntılarıyla açıklanmıştır. Betimsel analiz, doğrudan bir konunun resmedilmesi, tanımlanması ve açıklanmasını amaçlayan yöntemdir. Bu kapsamda sorulardan elde edilen verileri desteklemek üzere görüşmelerden doğrudan doğruya alıntılar alınmaktadır (Ekiz, 2009: 76).

\section{ANALIZ VE BULGULAR}

Araştırmada katılımcılara yöneltilen altı soruyla katılımcıların akıllı turizm destinasyonuna ilişkin görüşlerinin, akıllı turizm destinasyonlarının sağladığı faydaların, akıllı teknolojik sistemlerin işletmelerde kullanım durumlarının, işletmelerin mobil uygulamalardan faydalanma durumlarının, bölgedeki işletmelerin akıllı teknoloji ve uygulamaları kullanım durumuna ilişkin görüşlerinin ve akıllı teknolojilerin turizm sektöründe uygulanmasını engelleyen unsurların belirlenmesi amaçlanmıştır. Bu kapsamda elde edilen verilerin analizi neticesinde ulaşılan bulgular aşağıda gösterilmektedir. 
Tablo 3: İşletme Yöneticilerinin Akıllı Turizm Destinasyonuna İlişkin Görüşleri

\begin{tabular}{|c|c|}
\hline \multicolumn{2}{|r|}{ Konaklama İşletmeleri } \\
\hline İşletme I & $\begin{array}{l}\text { Turistin bölgeye ayak basmasından ayrılışına kadar nerede konaklayabilirim, nerede yemek } \\
\text { yiyebilirim, nasıl ulaşım sağlayabilirim, havalimanı transferini nasıl yapabilirim, hangi } \\
\text { işletmeler teknolojik araçlarla gezimi kolaylaştırabilir, şehirdeki trafik yoğunluğu nasıl } \\
\text { bunların hepsine bir takım uygulamalarla erişim sağlayabildiği ve turistlere tatilini kolay } \\
\text { kılan bir yapı sağlar. Akıllı turizm destinasyonları turistlere tatil sürecini kolaylaştıran bir } \\
\text { yapı sağlayarak, bölgesel imaja katkıda bulunan bir sistemdir. }\end{array}$ \\
\hline İşletme II & $\begin{array}{l}\text { Akıllı turizm destinasyonu dediğimiz olay insanların ellerindeki mobil cihazlarla veya diğer } \\
\text { teknolojik araçlarla bulundukları konumdaki sistemlerin birbiriyle entegre olması ve } \\
\text { bununla bulundukları konumda istedikleri şeylere kolayca erişebilme olanağına sahip } \\
\text { olmalarıdır diyebiliriz. Tramvay duraklarına ücretsiz Wi-fi hizmeti koymanı, bu sayede } \\
\text { yabancı birinin Eskişehir'e geldiğinde nereye ve nasıl gideceğini bilmesi, gideceğiniz yerde } \\
\text { bisiklet kullanabilecek misiniz işte bunların hepsinin entegrasyonu akıllı şehirdir. Biz bunu } \\
\text { akıllı turizmde kullanmaya çalışıyoruz. Türkiye'de bu, benden sonra vaktiniz olsa } \\
\text { bakarsınız, akıllık şehir ilk önce } 2015 \text { 'te Kayseri uygulandı. Şuanda en geniş şekilde } \\
\text { Antalya'da uygulanyor. }\end{array}$ \\
\hline \multicolumn{2}{|r|}{ Seyahat Acentaları } \\
\hline İşletme I & $\begin{array}{l}\text { İnsanların nereye gelmeliyim nasıl ulaşım sağlayabilirim gibi bilgilere kolayca erişmesi, } \\
\text { şehirlerde akıllı ekranların turistlere bilgi sağlaması, barkod sistemleri, mobil uygulamalar, } \\
\text { akıllı telefonlar bunlar hepsi akıllı turizm dolayısıyla akıllı destinasyonların bir bileşeni. } \\
\text { Örneğin, biz kültür turları kapsamında müzelere gidiyoruz orada akıllı telefonu olan birinin } \\
\text { barkod ile müzeleri gezerken bilgi elde etmesi. Tüm bunlar akıllı sistemlerin birbiriyle } \\
\text { entegrasyonuyla mümkün. Gelecekte turizm sektöründe dijitalleşmenin önü alınamaz gibi } \\
\text { görünüyor. Akıllı destinasyonlar gelecekte turizmde yerini önemli ölçüde alacak. }\end{array}$ \\
\hline İşletme II & $\begin{array}{l}\text { Günümüzde satış, rezervasyon, bilgilendirme gibi hizmetler teknoloji odaklı aynı zamanda } \\
\text { bilgisayar dili de gelişim gösteriyor, yani bireylerin bilgisayar kullanım oranı ve bilgisi } \\
\text { artıyor, böyle düşünüldüğ̈ünde teknoloji ağında akıllı turizm destinasyonları geleceğin } \\
\text { anlayışlarından biri olacaktır. }\end{array}$ \\
\hline \multicolumn{2}{|r|}{ Yiyecek ve İçecek İşletmeleri } \\
\hline İşletme I & $\begin{array}{l}\text { Akıllı turizm destinasyonlarının teknolojinin kullanımındaki en modern hali olduğunu } \\
\text { düşünüyorum. }\end{array}$ \\
\hline İşletme II & $\begin{array}{l}\text { Akıllı destinasyon, teknolojinin turizmi geliştirmede kullanabileceği en önemli sistemlerden } \\
\text { biridir. }\end{array}$ \\
\hline \multicolumn{2}{|r|}{ Eğlence İşletmeleri } \\
\hline İşletme I & $\begin{array}{l}\text { Akıllı turizm destinasyonları bölgelerin gelişmişliğini sağlama, piyasadaki işletmeleri } \\
\text { geliştirme açısından önemlidir. }\end{array}$ \\
\hline İşletme II & $\begin{array}{l}\text { Yakınlık artık fiziki yakınlıktan daha çok teknolojik yakınlığa evrilmiş durumda. Satış ve } \\
\text { pazarlamadan geri bildirime kadar, sipariş almadan rezervasyona ve ödeme sistemine kadar } \\
\text { tüm üretim sürecinde akıllı teknolojilerin kullanımını işletmeler için gereklilik haline gelecek. } \\
\text { Destinasyonlar bu akıllı sistemlere sahip işletmeciliği geliştirdikçe başarı elde edecek. } \\
\text { Dolayısıyla sektörde bu buna uygun adımlar atılmalıdır. }\end{array}$ \\
\hline
\end{tabular}


N. Kafa - R. Arıca - N. Sönmez Gök 12/3 (2020) 2774-2787

Tablo 3'teki bulgular incelendiğinde işletme yöneticilerinin akıllı teknoloji ve turizm destinasyonuna yönelik bilgi sahibi olduğu görülmektedir. Bu noktada konaklama işletmesi yöneticilerinin diğer işletme yöneticilerine göre akıllı turizm destinasyonlarını daha bütüncül bir bakış açısıyla değerlendirdiği görülmektedir. Bununla birlikte katılımcıların büyük bir bölümü, akıllı turizm teknolojilerinin bir gereklilik olduğunu ve gelecekte uluslararası ve ulusal düzeyde uygulamaya geçmesinin kaçınılmaz olacağı fikrinde birleşmektedir.

Tablo 4: Akıllı Turizm Destinasyonu Olmanın Sağladığı Fırsatlar

\begin{tabular}{|c|c|}
\hline $\begin{array}{l}\text { Örgütsel Faaliyetlere } \\
\text { Katkıları }\end{array}$ & $\begin{array}{l}\text { Üretim sürecinde zaman kaybını engeller }\left({ }^{*} \mathrm{~S}_{2}\right) \text {, } \\
\text { Pazarlama ve satış faaliyetlerini kolaylaştırır }\left({ }^{*} \mathrm{~K}_{1},{ }^{*} \mathrm{~S}_{1}, \mathrm{~S}_{2}\right) \\
\text { Yeniliği takip etmeyi sağlar }\left({ }^{*} \mathrm{E}_{1}\right) \\
\text { İşs süreçlerini verimli hale getirir }\left({ }^{*} \mathrm{E}_{2}\right) \\
\text { Yönetimsel süreçleri kolaylaştırır ve hızlandırır }\left(\mathrm{E}_{2}\right)\end{array}$ \\
\hline Ekonomik Katkıları & $\begin{array}{l}\text { Üretim maliyetlerini azaltır }\left({ }^{*} \mathrm{Y}_{2}\right) \\
\text { Pazarlama maliyetlerini azaltır }\left(\mathrm{S}_{2}\right)\end{array}$ \\
\hline Pazar Odaklı Firsatlar & $\begin{array}{l}\text { Bölgenin pazardaki rekabet gücünü arttırır }\left(\mathrm{K}_{1},{ }^{*} \mathrm{~K}_{2}, \mathrm{~S}_{2}, \mathrm{E}_{1}, \mathrm{E}_{2}\right) \\
\text { İşletmenin pazardaki rekabet gücünü geliştirir }\left(\mathrm{E}_{1}, \mathrm{~K}_{2}\right) \\
\text { Bölgeye talebi geliştirir }\left(\mathrm{K}_{1}, \mathrm{~K}_{2}\right) \\
\text { Gelecek neslin taleplerini karşılamayı olanaklı kılar }\left(\mathrm{K}_{1}\right) \\
\text { Bölgenin pazarda, pazarlamasını kolaylaştırır }\left(\mathrm{K}_{1}, \mathrm{~S}_{1}\right) \\
\text { Ürün ve hizmetleri daha bilindik kılmayı sağlar }\left({ }^{*} \mathrm{Y}_{1}, \mathrm{E}_{1}\right)\end{array}$ \\
\hline Hizmet Çıktılarına Katkıları & $\begin{array}{l}\text { Sunulan hizmet kalitesini geliştirir }\left(\mathrm{Y}_{1}, \mathrm{E}_{2}, \mathrm{~S}_{1}\right) \\
\text { İşletme imajını geliştirir }\left(\mathrm{Y}_{2}\right)\end{array}$ \\
\hline Müşteri Yönlü Fırsatlar & $\begin{array}{l}\text { Müşteri ve işletme arasındaki iletişimi sağlar }\left(\mathrm{K}_{1}, \mathrm{Y}_{1}\right) \\
\text { Müşteri ve işletme arasındaki etkileşimi kolaylaştırır }\left(\mathrm{K}_{1}\right) \\
\text { Müşteri ve işletme arasındaki bilgi transferini kolaylaştırır }\left(\mathrm{K}_{1}, \mathrm{~S}_{1}, \mathrm{Y}_{1}\right) \\
\text { Müşterinin bilgiye erişimini kolaylaştırır }\left(\mathrm{K}_{2}\right), \\
\text { Müşterilerin daha detaylı bilgilendirilmesini sağlar }\left(\mathrm{S}_{2}, \mathrm{Y}_{1}\right)\end{array}$ \\
\hline
\end{tabular}

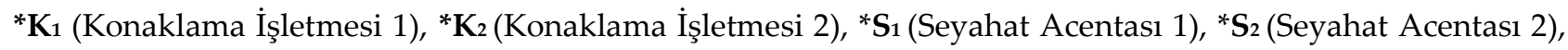
* $\mathbf{Y}_{1}$ (Yiyecek ve İçecek İşletmesi 1), * $\mathbf{Y}_{2}$ (Yiyecek ve İçecek İşletmesi 2), *E1 (Eğlence İşletmesi 1), * $\mathbf{E}_{2}$ (Eğlence İşletmesi 2)

Tablo 4'teki bulgular incelendiğinde katılımcıların akıllı turizm destinasyonunun sağladığı fırsatları farklı çerçevelerden değerlendirdiği görülmektedir. Buna göre; akıllı turizm destinasyonlarının örgütsel faaliyetler, ekonomik durum, pazar yönlü girişimler, hizmet çıktıları ve müşteri yönüyle bir takım fırsatlara olanak tanımaktadır. Katılımcıların çoğu, akıllı turizm destinasyonlarının pazardaki rekabet gücünü arttırdığına dair fikir sunmaktadır. Bununla birlikte pazarlama ve satış faaliyetlerine katkısı, hizmet kalitesini geliştirmesi ve bilgi transfer sürecini kolaylaştıııcı işlevi akıllı turizm destinasyonu olmanın oluşturacağı başlıca fırsatlar olarak görülmektedir.

Konaklama İşletmesi I: Bir araştırmaya göre gelecekte yeni neslin \%70'i turizm aktivitesi tercihlerinde teknolojiyle entegre bölgeleri tercih edecek. Doğal olarak teknolojiyi iyi kullanan bir nesil var ve akill bir destinasyon sisteminin yeni neslin çok çok çok dikkatini çekeceğini düşünüyorum ve ciddi anlamda potansiyel anlamında bölge ve işletmelerin artıya geçeceği, diğger destinasyonlara göre ciddi avantaj sağlayacağın düşünüyorum. 
Konaklama İşletmesi II: ...günümüz rekabet piyasası açısından en önemli şeylerden birisi bilişim, teknoloji ve teknolojiyi kullanma yeteneği. Bunu sağlayan bölge ve işletmelerin rekabet gücünü arttırması mümkündür. Şimdi dünya kişilerin avuçları arasında. Dolayısıyla eğer siz insanların avuçlarının arasında olan dünyayla teknolojiye uyum să̆layabiliyorsanız ve bilişimi kullanabiliyorsanız mutlaka diğer şehirlerden ve işletmelerden önde olacaksınız, tercih edilebilirliğiniz ve rekabet gücünüz artacak. Bu kaçınılmaz bir sonuç zaten.

Seyahat Acentası I: Birde müşterilerimizi dinlememize yardımcı oluyor, bir tıkla bize çok kolay ulaşıyorlar aradaki mesafe kalkıyor.

Yiyecek ve İçecek İşletmesi I: Bu sayede bölgedeki turizm işletmelerine ve bölgeye ilişkin bilgilerin daha sağhlkl, bilgi kirliliğinin daha az olduğu ve daha hızl erişim să̆layan yapılara erişebilmekteyiz. İnsanların hiç aklında yokken akıllı teknolojilerle müşterilerin bir anda aklına girip sizdeki ürünü almasını ya da konaklamasın sağlayabilirsiniz. Eskişehir'deki turistik çekicilikleri akıllı teknolojileri kullanarak tanıtabilir ve buraya gelen kişilerin farkındah̆̆ğı geliştirebiliriz.

Tablo 5: Akıllı Teknolojik Araçların Işsletmelerde Kullanım Durumu

\begin{tabular}{|c|c|c|c|c|c|c|c|}
\hline \multicolumn{2}{|c|}{$\begin{array}{c}\text { Konaklama } \\
\text { İşletmeleri }\end{array}$} & \multicolumn{2}{c|}{ Seyahat Acentaları } & \multicolumn{2}{c|}{$\begin{array}{c}\text { Yiyecek ve İçecek } \\
\text { Issletmeleri }\end{array}$} & \multicolumn{2}{c|}{ Eğlence İşletmeleri } \\
\hline Evet & Hayır & Evet & Hayır & Evet & Hayır & Evet & Hayır \\
\hline 2 & 0 & 2 & 0 & 1 & 1 & 2 & 0 \\
\hline
\end{tabular}

Tablo 5'te görüldüğ̈̈ üzere işletmelerin tamamına yakınının akıllı sistemlerle desteklenen modül ve uygulamaları kullanmaktadır. Buna göre katılımcıların akıllı teknolojik sistemlerin kullanımına dair açıklamaları şöyledir:

Konaklama İşletmesi I: Biz şu anda otelimizde ......hotels aplikasyonunu kullanıyoruz. Bunlarda rezervasyon dijital, online check-in ve diğer zamanlarda promosyonlar hakkında bilgiler sunuluyor. Aplikasyonumuz şu an Türkiye'de 250 bin kişi tarafindan indirilmiş ve biz bu sayede kendi şehrimizi e-marketing olarak tanttıyoruz ve şehrimize katkı sağhlyoruz. Her nerede olursa olsun müşteriler için hazırladığımız ve şehrimizi tanıtan kısa tanıtım videosunu onlara ulaştıriyoruz.

Seyahat Acentası II: Web sayfalarımız, sosyal iletişim ağı hesaplarımız, mobil uygulamalarımız var. Bunların hepsini müşteriyi bilgilendirmede kullanıyoruz. Öte yandan gelecekteki tüketici taleplerini de göz önüne alırsak bu araçların kesinlikle olması gerekli. Bu teknolojilerle ister engelli müşterilerimiz olsun, ister özel istekleri olan müşteriler, isterse normal müşterilerimiz olsun onlara faydalı olmaya isteklerini karşılamaya çalışıyoruz. Ve uygulamalarımızın kullanımı çok rahat.

Yiyecek İ̧ecek İşletmesi I: Misafirlerimizin böyle bir talebi olsa idi önceden sistemi kullanır hale gelebilirdik. Müşterilerimizin çoğu hala yüz yüze iletişimi benimsiyor, sanırım dijital ortam onlara samimiyetsiz geliyor.

Yiyecek İ̧ecek Isşletmesi II: Masalarımızda tabletler var. Menülerimiz yüklü. Tablette menü içerikleri var. Mesela alerjisi varsa misafirimiz kendi çıkarabilir menüden.

Ĕ̆lence İşletmesi II: Bilgisayar ve ek donanımlar rezervasyon süreçlerinde kullanıyoruz. Bununla birlikte, akıllı ekipmanlara sahibiz. Akıll kapı sistemleri, kamera sistemleri, web sitesi, dijital pişirme sistemleri ve barkod okuyucu sistemlerden faydalaniyoruz.

Tablo 6: Mobil Uygulamaların İsletmede Kullanım Durumu

\begin{tabular}{|c|c|c|c|c|c|c|c|}
\hline \multicolumn{2}{|c|}{$\begin{array}{c}\text { Konaklama } \\
\text { İşletmeleri }\end{array}$} & \multicolumn{3}{c|}{ Seyahat Acentaları } & \multicolumn{2}{c|}{$\begin{array}{c}\text { Yiyecek ve İçecek } \\
\text { İşletmeleri }\end{array}$} & \multicolumn{2}{c|}{ Eğlence İşletmeleri } \\
\hline Evet & Hayır & Evet & Hayır & Evet & Hayır & Evet & Hayır \\
\hline 2 & 0 & 2 & 0 & 2 & 0 & 1 & 1 \\
\hline
\end{tabular}


İşletmelerin mobil uygulamaya sahip olma durumlarına ilişkin katılımclların verdiği cevaplar incelendiğinde, bir işletme dışında tümünün mobil uygulamalara sahip olduğu görülmektedir. Akıllı turizm destinasyonlarında ve günümüz teknolojisinde mobil araç ve uygulamaların önemi dikkate alındığında, işletmelerde mobil uygulamaların mevcudiyetinin akıllı turizm şehrine geçiş sürecinde önem arz edeceği aşikârdır. Bununla birlikte işletmelerin yapıları farklılaştığından mobil uygulamaların kullanım amaçları farklılaşmaktadır.

Konaklama İşletmesi I: Bizim yetkili bir birimimiz var. Mobil uygulamalara onlar tarafindan takip edilip güncelleniyor. Misafirlerimiz istedikleri zaman aplikasyonlar cep telefonuna veya tabletine indirerek kullanabiliyor.

Seyahat Acentası I: Seyahat asistan olarak işlev görüyor. Müşteri doğrudan turla ilgili bilgi alabiliyor, mesajlaşma işlemlerimizi buradan gerçekleştirebiliyoruz ve satış işlemlerini buradan yapabiliyoruz.

Seyahat Acentası II: Pazardaki bilgi yapısı değiş̧ti. Bizde mobil uygulamaları genellikle müşterileri bilgilendirme doğrultusunda yaygin kullanıyoruz.

Yiyecek İçecek İşletmesi I: Burada aktifiz. Pazarlama faaliyetlerimizi, görsellerimizi, menülerimizi yeniledikçe güncelliyoruz. Eskişehir'e gelen biri restorandan yer ayıralım dediğinde mobil uygulamayla rezervasyonunuzu biz yapalım mı, yerinizi biz ayıralım mı sloganıyla sunduğumuz ve birçok sistemle bağlantılı mobil uygulamamız mevcut.

Yiyecek İçecek İşletmesi II: Mobil uygulamalarımız var. Müşteri restorana geldiğinde akıllı telefonundan bizim mobil uygulamamızı indirdiğinde çocuk menüsünün altında bir kare kod var, oradan menümüzdeki bütün ürünleri resimleriyle birlikte görebiliyor. Mobil uygulamayla çocuklarınızı oyun alanındayken canlı yayındaki gibi takip edebiliyorsunuz.

Ĕ̆lence İşletmesi I: Müşteriler işletmeye geldiğinde çalışanla yüz yüze iletişim kurmak istiyor. Bundan ötürü mobil uygulamaların işletmemizde kullanımı yok.

Tablo 7: Bölgedeki İşletmelerin Akıllı Teknolojik Araç ve Uygulamaları Kullanım Durumuna İlişkin Yöneticilerin Görüşleri

\begin{tabular}{|c|c|}
\hline \multicolumn{2}{|r|}{ Konaklama İşletmeleri } \\
\hline İşletme I & Yeterli düzeyde faydalanılmıyor. \\
\hline İşletme II & $\begin{array}{l}\text { Buna burada yerel yönetim destek vermesine karşın bence yeterince kullanılmıyor ve } \\
\text { önemsenmiyor. }\end{array}$ \\
\hline \multicolumn{2}{|r|}{ Seyahat Acentaları } \\
\hline İşletme I & Şuan ki o ortamda yeterli düzeyde kullanılmıyor. \\
\hline İşletme II & $\begin{array}{l}\text { Bence yetersiz sadece müşteri boyutuyla kalıyor, işletmeler halen kendi aralarında eski } \\
\text { sistemleri kullanıyor. }\end{array}$ \\
\hline \multicolumn{2}{|r|}{ Yiyecek ve İçecek İşletmeleri } \\
\hline İşletme I & $\begin{array}{l}\text { Evet, bölgedeki işletmelerin yeterince faydalandığını düşünüyorum. Satın alınan } \\
\text { ürünümüzü takip edebileceğimiz çok net bir şekilde kesin bilgiler veren bir ağ sistemine } \\
\text { sahibiz. }\end{array}$ \\
\hline İşletme II & Şehirde birçok işletmenin kullandığı sistemler mevcut. Dolaysıyla bence iyi noktadayız. \\
\hline \multicolumn{2}{|r|}{ Eğlence İşletmeleri } \\
\hline İşletme I & Bölgede ve işletmelerde yeterli düzeyde faydalanmiyoruz. \\
\hline İşletme II & $\begin{array}{l}\text { Kullanmıyoruz. Mobil ve akıllı cihazların bölgedeki işletmelere tarafından kullanımı } \\
\text { arttırılmalıdır. Sektörde buna uygun adımlar atılmalıdır. }\end{array}$ \\
\hline
\end{tabular}

Tablo 7'deki bulgulardan hareketle, katılımcıların bölgede ve işletmelerde akıllı teknolojik araç ve uygulamalardan yeterince faydalanılmadığını düşündüğü görülmektedir. Bu durum katılımcılar tarafından birçok unsurlar ilişkilendirilmektedir: talebin profili, talebin teknolojik bilgisinin yetersizliği, kalifiye personel azlığı, sistemi kullanan paydaşların azlığı bunların başlıcalarıdır.

Konaklama İşletmesi I: Bölgede yeterince kullanılmıyor. Aynı zamanda misafirlerde uygulamalar aracılığıyla işlem yapmaya alışkın değil, halen misafirlerimizin \% 65'i eski yöntemlerle rezervasyon yaptırıyor. Telefon, Faks, Elektronik posta gibi. Ama 10 yıl önce ile kıyasladığımızda müşterilerin akıllı teknolojileri kullanım oranı bayă̆ı arttı. Ama işletmelerin çoğu da hala eski sistemleri kullanıyor. Gelişmemiz lazım. 
Seyahat Acentası I: Şuan ki o ortamda yeterli düzeyde kullanılmıyor tabii alışılagelmiş bir anlayış var. Sistemlerde çok kolay değil ve entegre edilemiyor. Burada birazda alıcı etkili. Yaşı yüksek bireylerle çalışırsanız bunların hemen hemen hepsi eski sistemi tercih ediyor ancak genç kuşaktan bu konuda farkl talepler alıyoruz. Bana kalırsa evet ileride kesinlikle çok etkin olacaktır ama geçiş süreci için çok kolay olacağını düşünmüyorum açıkçası ama bunu ilk yapanlar önemseyenler her zaman bir adım önde olacaktır.

Yiyecek İ̧ecek İşletmesi II: Eskişehir'de uygulanmaya başlanılan bir sistem var TEK KART hatta Türkiye'de birçok yerde kullanılmaya başladı. Eskişehir'deki yerel firmalar birbirlerinde hem destek olmak açısından hem de misafirleri kendi arasında paylaşmak açısından kullanmaya başladılar. Örneğin bir yerel işletmede yemek yediğinizde puan kazanıyorsunuz, farklı bir yerel işletmede yine bu kartı kullandığınızda puan kazanıyorsunuz ve bu sistemdeki herhangi bir işletmede gidip toplam yüklenen puanı kullanabiliyorsunuz.

Tablo 8: Akıllı Teknolojilerin Turizm Sektöründe Uygulanmasını Engelleyen Unsurlar

\begin{tabular}{|c|c|}
\hline $\begin{array}{l}\text { Örgütsel Yapı Kaynaklı } \\
\text { Engeller }\end{array}$ & İşletmelerin yatırım yapma gönülsüzlüğü $\left({ }^{*} \mathrm{~K}_{1}\right)$ \\
\hline Çalışan Kaynaklı Engeller & Eğitimli personel bulma güçlüğü $\left(\mathrm{Y}_{2}, \mathrm{E}_{1}, \mathrm{E}_{2}\right)$ \\
\hline Ekonomik Engeller & $\begin{array}{l}\text { Ak1llı teknolojilerin maliyetlerinin yüksek olması }\left(\mathrm{K}_{1},{ }^{*} \mathrm{~K}_{2},{ }^{*} \mathrm{~S}_{2},{ }^{*} \mathrm{Y}_{2},{ }^{*} \mathrm{E}_{1},{ }^{*} \mathrm{E}_{2}\right) \\
\text { Ürün maliyetlerini arttırması }\left(\mathrm{S}_{2}\right)\end{array}$ \\
\hline Pazar Kaynaklı Engeller & $\begin{array}{l}\text { Talebin yetersizliği }\left(\mathrm{K}_{1},{ }^{*} \mathrm{~S}_{1},{ }^{*} \mathrm{Y}_{1}\right) \\
\text { Akıllı teknolojilerin mevcut pazardaki müşteri taleplerini karşılama } \\
\text { noktasında yetersiz olması }\left(\mathrm{Y}_{1}\right)\end{array}$ \\
\hline $\begin{array}{c}\text { Yerel Yönetimler Kaynaklı } \\
\text { Engeller }\end{array}$ & Yerel yöntemlerin desteğinin yetersiz olması $\left(\mathrm{K}_{1}\right)$ \\
\hline Bilgi Eksikliği & $\begin{array}{l}\text { Bilgi ve farkındalık yetersizliği }\left(\mathrm{S}_{1}\right) \\
\text { Akıllı turizm araçlarının kullanımı neticesinde müşteri sorunlarına } \\
\text { müdahale edecek yeteneklere sahip olamamamız }\left(\mathrm{Y}_{1}\right)\end{array}$ \\
\hline Altyapı Yetersizliği & $\begin{array}{l}\text { Akıllı sistemlerin kullanılacağı bir altyapının bölge ve işletmeler açısından } \\
\text { henüz yeterince gelişmemiş olması }\left(\mathrm{E}_{1}\right)\end{array}$ \\
\hline
\end{tabular}

${ }^{*} \mathbf{K}_{1}$ (Konaklama İşletmesi 1), *K (Konaklama İşletmesi 2), * $\boldsymbol{S}_{1}$ (Seyahat Acentası 1), * $\boldsymbol{S}_{\mathbf{2}}$ (Seyahat Acentası 2), *Y1 (Yiyecek ve İçecek İşletmesi 1), *Y $\mathbf{Y}_{2}$ (Yiyecek ve İçecek İşletmesi 2), *E1 (Eğlence İşletmesi 1), * E2 (Eğlence İşletmesi 2)

Katılımcıların akıllı turizm araç ve uygulamalarının kullanımını engelleyen unsurlara ilişkin görüşleri incelendiğinde, genel olarak ekonomik engeller sebebiyle akıllı turizm araç ve uygulamalarının kullanılmadığı konusunda hem fikir oldukları görülmektedir. Buna ilaveten; eğitimli personel, yani akıllı teknolojileri aktif ve verimli biçimde kullanacak personelin bulunamaması ve akıllı sistemlerle desteklenmiş işletme yapılarına talebin yetersizliği önemli engeller olarak ifade edilmektedir.

Konaklama İşletmesi I: Şöyle ki, şu an yeterli talep olmadı̆̆ı̆ndan işletmelerde ekonomik kaynaklarını buraya harcamaktan kaçıyor. Tabii işletmelerin büyük bir bölümünün de buna gücü yok. Bu noktada bölge olarak akıll sistemler kurulacaksa yetkililer destek olmal.

Seyahat Acentası I: Şimdi öncelikle tabii ki bulunduğumuz lokasyondaki talep yapısı ve talebin sosyo-ekonomik durumu kesinlikle etkileyecektir. Çünkü siz istediğiniz kadar sistemsel bir şey yapın. Kullanma talebinde bulunmayan insan olmadığı sürece bunu aktif hale getirmede çok zor olur. Öncelikle insanların bundan yarar görmesi gerekiyor yani bunu yaptığında ne gibi yararları olabilir diyor bununla ilgili farkındalık sağlamak lazım, buda bir zaman gerektiriyor.

Yiyecek İçecek İşletmesi I: Misafirlerimiz akşam geldiğinde masanın sahneye yakınlı̆̆ı, sesin rahatsı edici düzeyde olup olmadığını ya da masanın güneş görüp görmediğini ya da ısıtıcı olup olmadığııı bir aplikasyon ile bunu göremez. Biz kişisel deneyimlerimizi birleştirip müşterinin rahatsız olacağı bir şeyi tespit edip müşteri memnuniyetini kazanabiliyoruz. Müşterinin akıllı teknolojik araçlar kullanarak alacağı olumsuz cevap, mobil uygulama ya da aplikasyonun deneyime müdahale etme imkân düşük biz personelle ve deneyimle bu açı̆̆ı kapatabiliyoruz. 


\section{SONUÇ ve ÖNERİLER}

Bilgi ve iletişim teknolojilerinde son yıllarda yaşanan gelişmeler destinasyonlarda akıllı turizm uygulamalarının yaygınlaşmasını sağlamaktadır. Destinasyonlar seyahat öncesinde turistlere bölgeye ilişkin bilgi sunmak, seyahat sürecinde destinasyonla ilgili bilgilere daha kolay erişimini sağlamak ve seyahat sürecini kolaylaştırmak, seyahat sonrasında ise deneyimlerini paylaşmaları olanaklı kılmak üzere teknolojik sistemlerle entegre edilmiş yapılar kurmaktadır.

Mevcut araştırmada, Eskişehir destinasyonundaki turizm işletmesi yöneticilerinin akıllı turizm sistemlerine yönelik algıları, işletmelerde kullanılan akıllı teknolojik araç ve uygulamalar incelenmiştir. Sonuçlar işletme yöneticilerinin büyük çoğunluğunun akıllı turizm teknolojilerinin bir gereklilik olduğunu ve gelecekte bu uygulamaların öneminin daha da artacağını savunduklarını göstermektedir. Ayrıca işletme yöneticileri, akıllı turizm sistemlerinin destinasyon ve işletmelerin pazardaki rekabet gücünü arttırdığını belirtmektedir. Bu sonuç alan yazında desteklenmektedir. Nitekim Kuşat (2011), Koo vd. (2016), Liberato vd. (2018) yaptıkları çalışmalarda akıllı teknolojilerin turizm sektöründe rekabet avantajı sağladığını tespit etmiştir. Araştırmadaki bir diğer sonuç, turizm işletmelerinin akıllı turizm teknolojilerinin kullanımıyla sağlayacakları fırsatlara ilişkin farkındalıklarının olduğunu göstermektedir. Buna göre; akıllı teknoloji sistemler örgütsel yapıyı güçlendirmekte, işletmeye ekonomik katkı sunmakta, pazar ve müşteri yönlü faydalar sağlamakta ve işletmenin sunduğu hizmet çıtılarını geliştirmektedir. Arenas vd. (2019), Vecchio vd. (2018), Liberato vd. (2018) ve Le (2014) çalışmalarında akıllı teknolojilerle desteklenmiş sistemlerin bir takım fırsatları beraberinde getirdiğini belirlenmiştir. $\mathrm{Bu}$ açıdan değerlendirildiğinde araştırma sonuçlarının literatürle örtüştüğünü söylemek mümkündür.

Araştırmada elde edilen diğer bir sonuç işletmelerin tamamına yakınının akıllı sistemlerle desteklenen modül veya uygulamaları kullandıklarını göstermektedir. Bu kapsamda işletmelerin çoğu akıllı sistem olarak mobil uygulamalardan yararlanmaktadır. Elde edilen bu sonuç Drummond (2016) ve Dieck vd. (2016) tarafından hazırlanan çalışmalar tarafından desteklenmektedir. Bu çalışmalarda akıllı sistemler içerisinde mobil teknolojilerin uluslararası ölçekte en yaygın kullanılan araç ve uygulama olduğuna dikkat çekilmektedir. İşletme yöneticilerinin akıllı teknolojilerin turizm sektöründe kullanımını engelleyen unsurlara ilişkin görüşleri incelendiğinde, akıllı teknolojilerin altyapı maliyetlerinin yüksek olması ve pazardaki mevcut koşullar nedeniyle işletmelerde yeterince kullanılmadığı sonucuna varılmıştır. Ancak literatürde bazı çalışmalarda akıllı turizm uygulamalarının zaman içerisinde müşteri memnuniyetinin arttırılması, rekabet üstünlüğünün sağlanması, kâr marjının arttırılması ve maliyetlerin azaltılmasını mümkün kıldı̆̆ belirtilmektedir (Yalçınkaya vd., 2018: 47). Araştırmanın literatürle farklılaşan bu yönü şöyle açıklanabilir: Eskişehir'de akıllı sistemler işletme yapılarına yeni entegre edilmekte olduğundan yatırım aşamasında maliyetleri yüksek olmaktadır. Bun karşın akıllı sistemler işletmeler ve destinasyonlar için pazara uyum, değişen talebi karşılama, müşterilerle ilişkileri geliştirme, pazarlama gibi fırsatları uzun vadede üretmektedir. Bu noktada yatırım sürecinin ardından, bölgenin de akıllı sistemlerden fayda sağlayacağı aşikârdır.

Özetle; Eskişehir akıllı turizm sistemlerine yeni entegre olan turistik destinasyonlardan biridir. Akıllı sistemler bölgede yatırım ve gelişim aşamasında iken, işletmelerde uygulanma düzeyi farklılık göstermektedir. Mobil uygulamalar akıllı teknolojiler içerisinde pratikte kullanımın en fazla geliştiği sistemdir. Bununla birlikte yapay zekâ ve giyilebilir teknolojik sistemlere ilişkin gelişimin yeterli düzeyde olmadığı görülmektedir. Bu noktada işletmelerde akıllı sistemlerin uygulanmasını engelleyen unsurlar ön plana çıkmaktadır. Nitekim işletme yöneticilerinin çoğunun akıllı teknolojiler ve kullanımının işletmelerine sağlayacağı fırsatlara ilişkin bilgi ve farkındalıkları vardır. Bu farkındalık engellerin kaldırılması veyahut azaltılmasıyla eğilimlerin artış göstereceğine dair ipuçları sunmaktadır. İşletme yöneticilerine göre akıllı sistemlerin Eskişehir'de uygulanmasını engelleyen unsurlar başta ekonomik yetersizlikler olmak üzere, altyapı sorunları, kalifiye çalışan bulamama ve pazar odaklı sorunlardır. Bu noktada ulusal ve bölgesel düzeyde gerçekleştirilecek girişimlerle söz konusu engellerin ortadan kaldırılması veya azaltılması mümkündür. İşletmelerin çeşitli kuruluşlar, projeler veya destinasyon yönetimleri tarafından ekonomik açıdan desteklenmeleri sürece entegre olmalarını teşvik edecektir. Aynı zamanda bölgede hâlihazırda yürütülen ve gelecekte yürütülecek akıllı şehir projelerinin zaman içerisinde altyapı kaynaklı engelleri azaltacağı aşikârdır. Bir diğer engel olarak görülen akıllı teknolojileri aktif ve verimli biçimde kullanacak kalifiye çalışan bulma güçlüğünün eğitim kurumlarının desteği yanı sıra kamu ve özel işbirlikleriyle düzenlenen kurslarla aşılması olasıdır. Bu noktada özellikle turizmle ilgili olan eğitim öğretim kurumlarında ilgili derslerin müfredatlara eklenmesi gerekmektedir. Diğger 
yandan özellikle staj sürecinde eğitim kurumları ve işletmeler arasındaki koordinasyon aracılı̆̆ıla oryantasyon eğitimlerine de desteklerin sağlanması önemlidir. Destek ve kalifiye çalışanların artışı sektörde akıllı sistemleri kullanan paydaş sayısının arttırmasını teşvik edecektir. Akıllı sistemlerin örgütsel, ekonomik, müşteri ve hizmet çıtısı odaklı faydaları bir arada düşünüldüğünde, gerekli altyapı koşulları oluşturulduğunda, bu sistemlerin bir destinasyon olarak Eskişehir'in ve işletmelerin rekabet gücünün gelişimine yardımcı olacağı aşikardır. Ayrıca uluslararası düzeyde yaşanan COVID19 pandemisiyle pazarda artan durağanlık hijyen ve sağlık açısından teknolojik uyum ve entegrasyonu önemli kılmaktadır. Bu bağlamda akıllı sistemlerin bölgeler ve işletmelerde uygulamaya geçirilmesi, kısa vadede faydaların elde edilmesine yardımcı olması açısından önemlidir.

Çalışmada akıllı sistemlerle desteklenmiş işletme yapılarına odaklanılmıştır. Ancak çalışmada da belirlendiği üzere işletmelerin akıllı sistemleri kullanmalarını engelleyen bir unsur da talebin yetersizliğidir. Bu bakımdan akıllı sistem konusunda ileride yapılacak çalışmalarda talep boyutunun incelenmesi ve talebin bu konudaki isteklerinin saptanması konunun daha detaylı şekilde incelenebilmesine olanak sağlayacaktır.

\section{KAYNAKÇA}

Afsarmanesh, H. ve Camarinha-Matos, L.M. (2000). Future smart-organizations: A virtual tourism enterprise, In Proceedings Of The First International Conference On Web Information Systems Engineering, (1): 456-461.

Aksoğan, M. ve Çalış Duman, M. (2018). Akıllı Şehir Uygulamaları: Malatya Örneği. Uluslararası Battalgazi Multi Disiplinler Çalışmalar Kongresi, Malatya, Türkiye, 7-9 Aralık, 183-202.

Arenas, Alvaro E., Goh, J.M. ve Urueña, A. (2019). How does IT affect design centricity approaches: Evidence from Spain's smart tourism ecosystem, International Journal of Information Management. 45: 149-162.

Arıca, R. (2019). Seyahat acentalarında turistik ürünlerin kişiselleştirilmesinin bir yolu olarak müşterilerle üretim. Türk Turizm Araştırmaları Dergisi, 3 (3): 499-516.

Barrionuevo, J. M., Pascual, B. ve Ricart, J.E. (2012). Smart Cities, Sustainable Progress: Opportunities for Urban Development. Third Quarter, 14: 50-57.

Boes, K., Buhalis, D. ve Inversini, A. (2016), Smart tourism destinations: Ecosystems for tourism destination competitiveness, International Journal of Tourism Cities, 2(2): 108-124.

Buhalis, D. ve Amaranggana, A. (2013). Smart tourism destinations. Information and Communiacation Technologies in Tourism: 553-564.

Buonincontri, P. ve Micera, R. (2016), The experience co-creation in smart tourism destinations: A multiple case analysis of European destinations, Information Technology \& Tourism, 16: 285-315.

Çelik, P. ve Topsakal, Y. (2017), Akıllı turizm destinasyonları: Antalya destinasyonunun akıllı turizm uygulamalarının incelenmesi, Seyahat ve Otel İşletmeciliği Dergisi, 14 (3): 149-166.

Çevre ve Şehircilik Bakanlığı (2019). 2019 - 2022 Ulusal Akıllı Şehirler Stratejisi ve Eylem Planı, Akıllı Şehirler Beyaz Bülteni, Türkiye Cumhuriyeti Çevre ve Şehircilik Bakanlığı, Coğrafi Bilgi Sistemleri Genel Müdürlüğü.

Dieck, M. C. T., Jung, T. ve Han, D.I. (2016). Mapping requirements for the wearable smart glasses augmented reality museum application. Journal of Hospitality and Tourism Technology, 7 (3): 230-253.

Drummond, M. (2016). 5 Great Ways Airlines Are Using Internet Of Things. Erişim Linki: https://w3.accelya.com/blog/5-great-ways-airlines-are-using-theinternet-of-things. Erişim Tarihi: 05.06.2020.

Ekiz, D. (2009). Bilimsel Araştırma Yöntemleri. (2. Baskı). Ankara: Anı Yayıncılık.

Giffinger, R., Fertner, C. Kalasek, R. ve Milanovic, N.P. (2007). Smart cities-Ranking of European mediumsized cities. Vienna University of Technology. Final Report, pp: 1-28.

Graziano, T. (2014), Boosting innovation and development? The Italian smart tourism: A critical perspective, European Journal of Geography, 5 (4): 6-18. 
Gretzel, U., Fesenmaier, D. R. ve O'Leary, J. T. (2006). Transformation of Consumer Behaviour. D. Buhalis ve C. Costa (Ed.). In Tourism Business Frontiers: Consumers, Products and Industry. Oxford: Routledge.

Gretzel, U., Sigala, M., Xiang, Z. ve Koo, C. (2015). Smart tourism: Foundations and developments, Electronic Markets, 25: 179-188.

Gretzel, U., Werthner, H., Koo, C. ve Lamsfus, C. (2015), Conceptual foundations for understanding smart tourism ecosystems. Computers in Human Behavior, 50: 558-563.

Guo, Y., Liu, H., ve Chai, Y. (2014). The embedding convergence of smart cities and tourism internet of things in China: An advance perspective. Advances in Hospitality and Tourism Research, 2 (1): 54-69.

Karayılmaz, C. ve Özker, N. A. (2020). Kamusal nitelikli özel malların sunumunda akıllı şehirler olgusu: Akıllı Şehir uygulamalarında küresel değişimler. KMÜ Sosyal ve Ekonomik Araştırmalar Dergisi. 22 (38): 82100.

Khan, M. S., Woo, M., Nam, K. ve Chathoth, P. K. (2017). Smart city and smart tourism: case of Dubai. Sustainability, 9 (12): 2279.

Koo, C., Shin, S., Gretzel, U., Hunter, W.C. ve Chung, N. (2016), Conceptualization of smart tourism destination Competitiveness. Asia Pacific Journal of Information Systems, 26 (4): 561-576.

Kozak, M. (2014). Bilimsel Araştırma: Tasarım, Yazım ve Yayım Teknikleri. Ankara: Detay Yayıncılık.

Kuşat, N. (2011), Küreselleşen dünyada turizm sektörü: Bilgi iletişim teknolojileri ve rekabet gücü, Akademik Araştırmalar ve Çalışmalar Dergisi, 3 (5): 114-138.

Lamsfus, C., Wang, D., Alzua-Sorzabal, A. ve Xiang, Z. (2015). Going mobile: defining context for on-thego travelers, Journal of Travel Research, 54 (6): 691-701.

Lazaroiu, G.C. ve Roscia, M. (2012). Definition methodology for the smart cities model. Energy, 47 (1): 326-332.

Li Y., Hu, C., Chao, H. ve Liqiong, D. (2017). The concept of smart tourism in the context of tourism information services. Tourism Management 58: 293-300.

Liberato, P., Alen, E. ve Liberato, D. (2018). Smart tourism destination triggers consumer experience: The case of Porto. European Journal of Management and Business Economics, 27 (1): 6-25.

Le, T. V. N. (2014). Technology Enhanced Tourist Experience: Insights From Tourism Companies in Rovaniemi, Thesis Lapland University. Finland.

Lopez De Avila, A. (2015). Smart Destinations: XXI Century Tourism. ENTER2015 Conference On Information and Communication Technologies in Tourism, Lugano, Switzerland.

Polese, F., Botti, A., Grimaldi, M., Monda, A. ve Vesci, M. (2018), Social innovation in smart tourism ecosystems. How technology and institutions shape sustainable value co-creation, Sustainability, 10 (140): $1-24$.

Wang, D., Li, X. ve Li, Y. (2013). China's "smart tourism destination" initiative: A taste of the service-dominant logic. Journal of Destination Marketing and Management, 2 (2): 59-61.

Vecchio, P.D., Mele, G., Ndou, V. ve Secundo, G. (2018), Creating value from social big data: Implications for smart tourism destinations, Information Processing and Management, 54 (5): 847-860.

Yalçınkaya, P. Atay, L. ve Karakaş, E. (2018), Akıllı turizm uygulamaları, Gastroia: Journal of Gastronomy and Travel Research, 2 (2): 34-52.

Zhang, L. (2012). Smart tourism: The coming age of customization and intelligent public services. Journal Of Tourism Tribune, 27 (2): 3-5.

Zencir, B. ve Emir., O. (2019) Smart applications in the hospitality business : A qualitative study on the city of Eskişehir, Journal of Business Research-Turk, 11 (4): 2601-2611.

www.tepebasi.bel.tr Erişim Tarihi: 05.07.2020 